J. Lake Sci. (湖泊科学), 2015, 27(2): 208-215

http: //www.jlakes. org. E-mail : jlakes@niglas.ac.cn

(C) 2015 by Journal of Lake Sciences

\title{
太湖流域上游西莟溪支流的营养状态特征及成因分析”
}

\author{
王欢, 袁旭音林, 陈海龙, 许海燕, 李正阳 \\ (河海大学环境学院,南京 210098)
}

\begin{abstract}
摘 要: 为了解太湖流域上游支流水体的营养状态特征及流域附近土地利用对水质的影响, 选取了人湖水系西芳溪的 10 条主要支流进行了野外采样和实验室研究. 研究结果表明, 支流总磷 (TP)、颗粒磷 (PP)、总溶解性磷 (TDP)、总氮 (TN)、 铵态氮 $\left(\mathrm{NH}_{4}^{+}-\mathrm{N}\right)$ 、硝态氮 $\left(\mathrm{NO}_{3}^{-}-\mathrm{N}\right)$ 含量季节间差异较大, $\mathrm{TP}$ 含量范围为 $0.033 \sim 0.205 \mathrm{mg} / \mathrm{L}, \mathrm{PP}$ 含量范围为 $0.007 \sim$ $0.104 \mathrm{mg} / \mathrm{L}$, TN 含量范围为 $2.014 \sim 5.921 \mathrm{mg} / \mathrm{L}, \mathrm{NH}_{4}^{+}-\mathrm{N}$ 含量范围 $0.021 \sim 1.659 \mathrm{mg} / \mathrm{L}, \mathrm{NO}_{3}^{-}-\mathrm{N}$ 含量范围 $1.082 \sim 3.415$ $\mathrm{mg} / \mathrm{L}$, COD 范围为 $6.5 \sim 15.5 \mathrm{mg} / \mathrm{L}$. 总体上呈现为枯水期 > 平水期 > 丰水期. 部分支流受到不同程度的氮污染. 利用水质 参数进行聚类分析, 可以将 10 条支流分成 4 类, 其水体营养特征与周围环境相联系. 支流营养盐、COD 的通量明显受流量 控制, 表现为丰水期 > 平水期 > 枯水期. 土地利用类型的差异是导致其水质变化的主要原因,耕地和居民地主要起源的 作用,林地和草地主要起汇的作用. 在丰水期和枯水期, 对各指标影响最大的土地利用类型为耕地和林地; 在平水期, 对 $\mathrm{TP}$ 影响最大的是居民地,而对 TN 影响最大的是林地.
\end{abstract}

关键词: 营养盐;COD;流量;土地利用类型;支流;西苔溪;太湖流域

\section{Water nutrient status and its controlling factors in the inflow tributaries of Xitiaoxi River, upper reaches of Lake Taihu basin}

\author{
WANG Huan, YUAN Xuyin, CHEN Hailong, XU Haiyan \& LI Zhengyang \\ ( College of Environment, Hohai University, Nanjing 210098, P. R. China)
}

\begin{abstract}
In order to investigate the differences of nutrient status of tributaries in Lake Taihu basin and the impact of land use on water quality, ten tributaries of Xitiaoxi River were chosen. Total phosphorus ( TP), particle phosphorus ( PP), total nitrogen $(\mathrm{TN})$, ammonia nitrogen $\left(\mathrm{NH}_{4}^{+}-\mathrm{N}\right)$, nitrate $\left(\mathrm{NO}_{3}^{-}-\mathrm{N}\right)$, chemical oxygen demand ( COD) values of tributary waters were $0.033-$ $0.205,0.007-0.104,2.014-5.921,0.021-1.659,1.082-3.415$ and $6.5-18.5 \mathrm{mg} / \mathrm{L}$, respectively. The concentration of nutrients and COD had a significant temporal variation in the following orders: dry season $>$ normal season $>$ wet season. The tributaries were polluted at various levels. TN concentrations of waters were high in some tributaries. The tributaries can be divided into four categories according to the clustering analysis on nutrient parameters. Fluxes of nutrients and COD showed from high to low amount in the order: wet season $>$ normal season $>$ dry season, which indicated that they were mainly controlled by discharge. Land use was the most important factor affecting water quality in tributaries of Xitiaoxi River. Cultivated land, residential area had a positive impact on water quality, while there were negative correlation between water quality and the forestland, grassland. In wet season and dry season, cultivated land and forestland had the most important impact on nutrients and COD, while in normal season, residential land and forestland had the most remarkably important influence on TP and TN, respectively.
\end{abstract}

Keywords: Nutrients; COD; fluxes load; land use type; tributaries; Xitiaoxi River; Lake Taihu basin

氮、磷营养盐是生物体必需元素, 同时也是引起水体富营养化的主要影响因素. 水体的氮、磷分布也是 区域水生态环境的反映 ${ }^{[1-3]}$. 近年来, 随着经济发展, 人类活动日益剧烈, 我国河流水体中营养元素质量浓度 有上升趋势 ${ }^{[4-6]}$, 营养盐质量浓度上升会导致河流水体富营养化风险增加, 是河流水环境治理的重要问题

* 国家自然科学基金项目 (41372354) 和科技部国际科技合作专项 (2012DFA60830) 联合资助. 2014-02-26 收稿; 2014-08-11 收修改稿. 王欢(1989 ), 女, 硕士研究生; E-mail : why20131207@ 126. com.

** 通信作者;E-mail:yxy_hjy@hhu. edu.cn. 

之一 ${ }^{[7]}$.

西苕溪是太湖的主要人湖水系, 近年来由于经济的发展和土地利用的调整, 林地地区被大量开圼为坡 耕地、耕地; 氮肥的大量施用、城市化的加快也使大量氮、磷污染物排人太湖下游, 增加了太湖的氮、磷人湖 负荷 ${ }^{[8-9]}$. 由于土地利用和来源的不同, 西苕溪流域上、中、下游地区各个支流小流域氮素输出强度差异很 $大^{[10]}$. 耕地产生的污染物负荷要高于其他土地利用类型 ${ }^{[11]}$. 西苕溪流域营养盐输出水平空间差异性明显, 小流域单元优势土地利用类型与营养盐输出关系明显 ${ }^{[12]}$. 尽管已有一些关于西苕溪流域水体营养状态的研 究, 但大多集中在西苕溪干流, 对西苕溪支流的营养状态的差异性及营养盐输出的研究还比较少, 而支流水 体的营养水平是流域水污染控制的重要内容.

本实验选取西苕溪主要支流作为研究对象, 针对区域水体富营养化问题, 通过对丰水期、平水期和枯水 期水质进行检测、统计, 对苕溪支流氮、磷营养盐含量变化、输出负荷进行分析, 并从土地利用类型的角度分 析水质变化的成因, 以期为西苕溪乃至太湖的富营养化研究提供参考.

\section{1 材料和方法}

\section{1 研究区域概况}

西苕溪位于太湖流域上游, 是其主要 人湖水系之一. 西苕溪主源为西溪, 有数十 条主要支流汇流而人. 支流流域属亚热带 季风气候区,降雨主要集于 4-9 月. 本研究 的采样点分布如图 1 所示.

利用 2010 年的 TM/ETM 遥感影像数 据获得西宕溪流域的土地利用数据, 并对 支流小流域进行实地勘察修正, 根据研究 目标以及遥感影像的精度, 将土地利用类 型分为林地、耕地、草地和居民地 4 大类. 结 合全流域土地利用现状图, 获得各支流流 域不同土地利用类型的面积和相应的百分 比,作为进一步分析土地利用结构对西苕 溪支流水质影响的基础. 西苕溪支流土地 利用类型以林地为主, 其次为耕地、居民 地、草地(图 2).

\section{2 样品采集和处理}

在 2013 年 7、10 和 12 月, 对西芳溪的 10 条支流进行了 3 次集中采样. 以 7 月代 表丰水期,10 月代表平水期,12 月代表枯水 期. 按水样采集规范 ${ }^{[13]}$, 根据不同支流的宽 度, 各断面分别设置 $1 \sim 3$ 个采样点, 采集 $0.5 \mathrm{~m}$ 以上表层水. 同一断面超过 1 个采样 点时, 取平均值代表断面平均水质状况. 同 时使用 LB70-1C 悬杯式流速仪对各断面的 流速进行检测.

\section{3 样品分析方法}

水质理化监测项目为总磷 $(\mathrm{TP})$ 、总溶 解磷 $(\mathrm{TDP})$ 、总氮 $(\mathrm{TN})$ 、铵态氮 $\left(\mathrm{NH}_{4}^{+}-\mathrm{N}\right)$ 、 硝态氮 $\left(\mathrm{NO}_{3}^{-}-\mathrm{N}\right)$ 、化学需氧量 $(\mathrm{COD}) 、 \mathrm{pH}$ 、

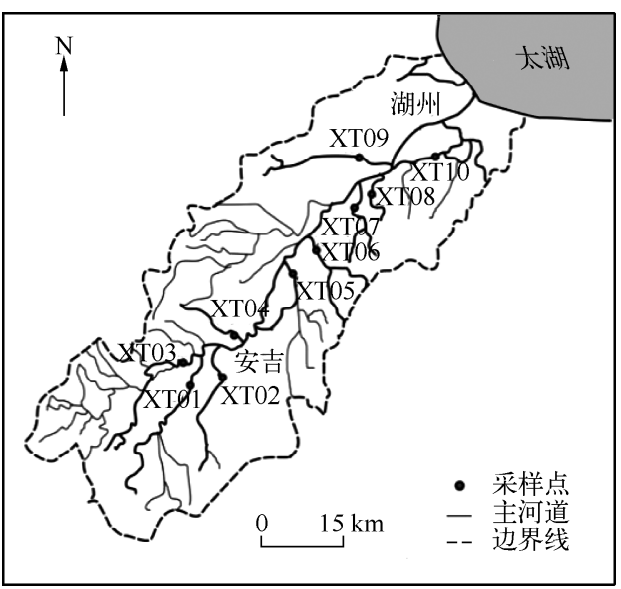

图 1 采样点分布

Fig. 1 Distribution of the sampling sites

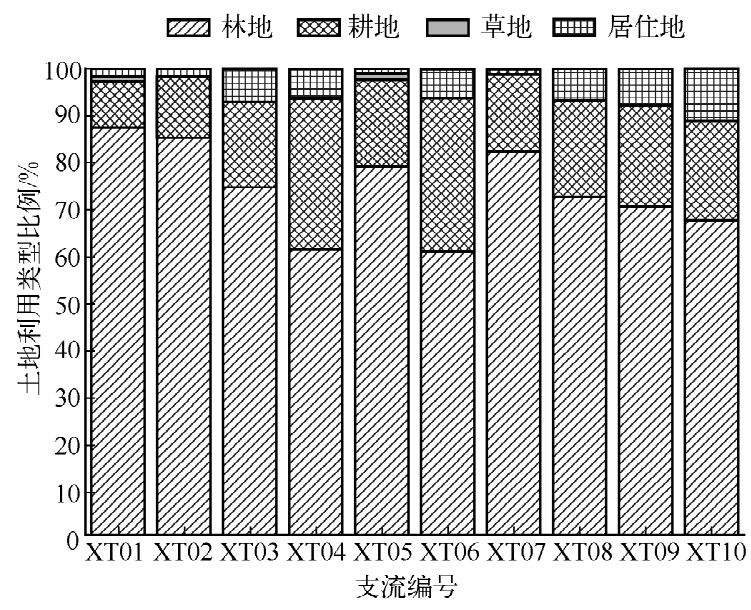

图 2 西苕溪支流流域土地利用结构

Fig. 2 Land use composition of tributaries of Xitiaoxi River 
溶解氧 ( DO ) 、电导率、水温. 其中 $\mathrm{pH} 、 \mathrm{DO}$ 、水温、电导率、COD 采用多功能水质检测仪进行现场检测; TN 采用 碱性过硫酸钾氧化法测定; $\mathrm{NO}_{3}^{-}-\mathrm{N}$ 采用紫外分光光度法测定; $\mathrm{NH}_{4}^{+}-\mathrm{N}$ 采用纳氏试剂法测定; $\mathrm{TP}$ 和 TDP 采用 过硫酸钾氧化法测定. 为了控制测定的准确性, 在 $\mathrm{TN} 、 \mathrm{TP} 、 \mathrm{NH}_{4}^{+}-\mathrm{N} 、 \mathrm{NO}_{3}^{-}-\mathrm{N}$ 分析时, 每 10 个测定样品用标准 样品校验. 另 $10 \%$ 的平行样分析用于控制实验的精密度, 平行样的相对误差小于 $10 \%$. 水质数据按照地表水 环境质量标准 (GB3838-2002) 来进行分析.

\section{2 结果与分析}

\section{1 水体理化参数特征}

西苕溪主要支流丰水期、平水期和枯水期 $\mathrm{pH}$ 范围为 $5.67 \sim 7.71$, 均为中偏弱酸性水体; $\mathrm{DO}$ 含量范围为 $3.62 \sim 8.02 \mathrm{mg} / \mathrm{L}$. XT06 这条支流, 采样点位于红山村, 附近有矿山开采, 水中有大量运沙船通过, 水质浑浊, 夏季污染重、水温高, 底泥厌氧发酵导致丰水期 DO 较低, 其余饱和率范围为 $60 \% \sim 102 \%$. 受水温的影响, 大 部分河流 DO 含量枯水期大于平水期和丰水期. 受水体流速的影响, DO 饱和率枯水期小于平水期和丰水期; 电导率范围为 $123 \sim 459 \mu \mathrm{S} / \mathrm{cm}$, 一些支流的电导率是枯水期大于平水期和丰水期, 可能与枯水期水体流量 小、工业污染源排放相对量增加有关 (表 1 ).

\section{表 1 西苕溪支流理化参数}

Tab. 1 Results of physical chemistry parameters of tributaries of Xitiaoxi River

\begin{tabular}{|c|c|c|c|c|c|c|c|c|c|c|c|c|}
\hline \multirow{2}{*}{$\begin{array}{l}\text { 支流 } \\
\text { 编号 }\end{array}$} & \multicolumn{3}{|c|}{ 水温 $/{ }^{\circ} \mathrm{C}$} & \multicolumn{3}{|c|}{$\mathrm{pH}$} & \multicolumn{3}{|c|}{$\mathrm{DO} /(\mathrm{mg} / \mathrm{L})$} & \multicolumn{3}{|c|}{ 电导率/ $(\mu \mathrm{S} / \mathrm{cm})$} \\
\hline & 7 月 & 10 月 & 12 月 & 7 月 & 10 月 & 12 月 & 7 月 & 10 月 & 12 月 & 7 月 & 10 月 & 12 月 \\
\hline XT01 & 22.5 & 18.5 & 10.5 & 7.71 & 7.45 & 7.26 & 7.97 & 7.85 & 8.02 & 218 & 201 & 208 \\
\hline ХT02 & 28.5 & 23.0 & 11.5 & 6.72 & 6.55 & 7.42 & 7.15 & 7.20 & 7.28 & 292 & 225 & 250 \\
\hline ХT03 & 31.8 & 28.0 & 13.5 & 6.98 & 6.75 & 7.25 & 6.45 & 6.53 & 7.02 & 123 & 149 & 186 \\
\hline ХT04 & 30.5 & 28.5 & 13.0 & 6.58 & 6.70 & 7. 12 & 5.73 & 5.68 & 6.98 & 203 & 198 & 241 \\
\hline ХT05 & 31.5 & 27.0 & 13.6 & 7.27 & 7.13 & 7.25 & 6.10 & 7.05 & 7.32 & 170 & 175 & 185 \\
\hline ХT06 & 32.0 & 27.9 & 15.0 & 7.27 & 6.95 & 7. 15 & 3.62 & 5.65 & 6.02 & 459 & 350 & 268 \\
\hline ХT07 & 31.8 & 25.5 & 13.5 & 6.98 & 7.05 & 7.25 & 4.88 & 6.57 & 7.12 & 180 & 197 & 218 \\
\hline ХT08 & 32.5 & 27.5 & 12.0 & 7.01 & 6.80 & 7.22 & 6.88 & 6.75 & 7.25 & 165 & 182 & 189 \\
\hline ХT09 & 30.0 & 26.0 & 14.5 & 5.67 & 6.75 & 7.05 & 7.39 & 6.78 & 6.95 & 202 & 195 & 212 \\
\hline XT10 & 32.5 & 28.5 & 15.8 & 7.46 & 7.05 & 7. 13 & 6.50 & 6.68 & 6.83 & 183 & 250 & 271 \\
\hline
\end{tabular}

\section{2 营养元素及其形态特征}

西苕溪支流磷、氮含量变化如图 3 所示. TP 含量范围为 $0.033 \sim 0.205 \mathrm{mg} / \mathrm{L}$, 除了 XT08 支流, 其他所有 支流的 TP 含量均优于 II 类水标准. 颗粒态磷 $(\mathrm{PP})$ 的含量范围为 $0.007 \sim 0.104 \mathrm{mg} / \mathrm{L}$, TDP 含量为 $0.012 \sim$ $0.101 \mathrm{mg} / \mathrm{L}$. 除了丰水期的支流 XT02、XT09 外, PP 为其余支流磷的主要赋存形态, PP/TP 值在 51. 7\% $83.3 \%$ 之间. 大部分支流的磷含量均表现为枯水期 $>$ 平水期 $>$ 丰水期. 与干流相比 ${ }^{[14-15]}$, 大部分支流的磷含 量低于干流.

$\mathrm{TN}$ 含量在 $2.014 \sim 5.921 \mathrm{mg} / \mathrm{L}$ 之间. $\mathrm{NH}_{4}^{+}-\mathrm{N}$ 含量在 $0.021 \sim 1.659 \mathrm{mg} / \mathrm{L}$ 之间, 除了 XT04 的丰水期含 量达到 IV 类水外, 其余河流均能达到 $\mathrm{I} \sim$ III 类水质标准. $\mathrm{NO}_{3}^{-}-\mathrm{N}$ 含量在 $1.082 \sim 3.415 \mathrm{mg} / \mathrm{L}$ 之间, 除了 XT04 这条支流外, 其余支流的 $\mathrm{NO}_{3}^{-}-\mathrm{N}$ 都占 $\mathrm{TN}$ 的 51.7\% 以上, 为 $\mathrm{TN}$ 的主要赋存形式, 而水体氮素常以还原 态及氧化态两种形式存在, 还原态 $\mathrm{NH}_{4}^{+}-\mathrm{N}$ 含量降低, 而氧化态 $\mathrm{NO}_{3}^{-}-\mathrm{N}$ 含量上升, 在一定程度上意味着水体 环境氧化能力有提升的趋势, 水体自净能力较高 ${ }^{[16]}$. 绝大部分支流的 $\mathrm{TN} 、 \mathrm{NH}_{4}^{+}-\mathrm{N} 、 \mathrm{NO}_{3}^{-}-\mathrm{N}$ 含量均表现为枯 水期 $>$ 平水期 $>$ 丰水期. 与干流相比 ${ }^{[14]}$, 支流的 $\mathrm{TN}$ 含量大于干流,加重干流氮污染.

对 $\mathrm{TP} 、 \mathrm{PP} 、 \mathrm{TN} 、 \mathrm{NH}_{4}^{+}-\mathrm{N}$ 和 $\mathrm{NO}_{3}^{-}-\mathrm{N}$ 进行无重复双因子方差分析, 结果表明各支流 $\mathrm{TP} 、 \mathrm{PP} 、 \mathrm{TN} 、 \mathrm{NH}_{4}^{+}-\mathrm{N}$ 和 $\mathrm{NO}_{3}^{-}-\mathrm{N}$ 含量时空分布基本均有显著差异, 这与西苕溪附近的农业耕作方式和地表径流的季节变化有关.

COD 可以作为有机污染的指标. 西苕溪支流的 COD 范围在 $6.5 \sim 15.5 \mathrm{mg} / \mathrm{L}$ 之间, 达到 I II 类水质 


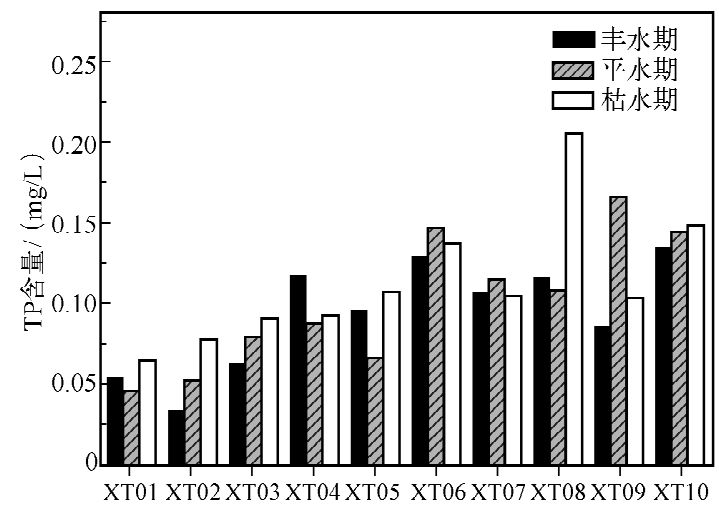

文流编只

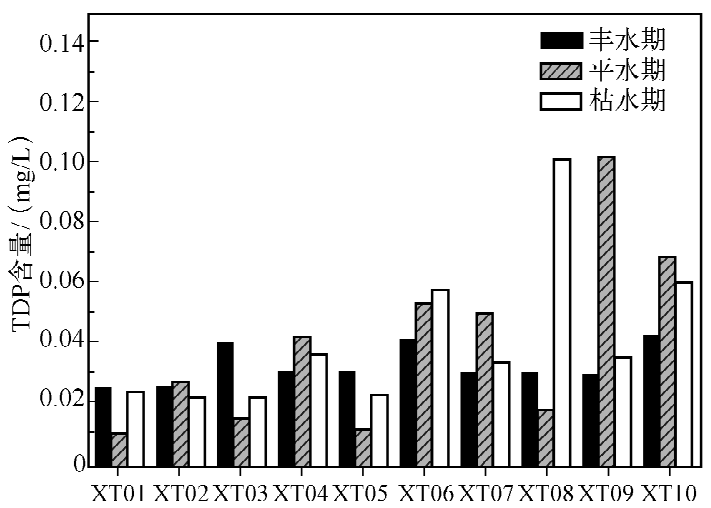

支流编号

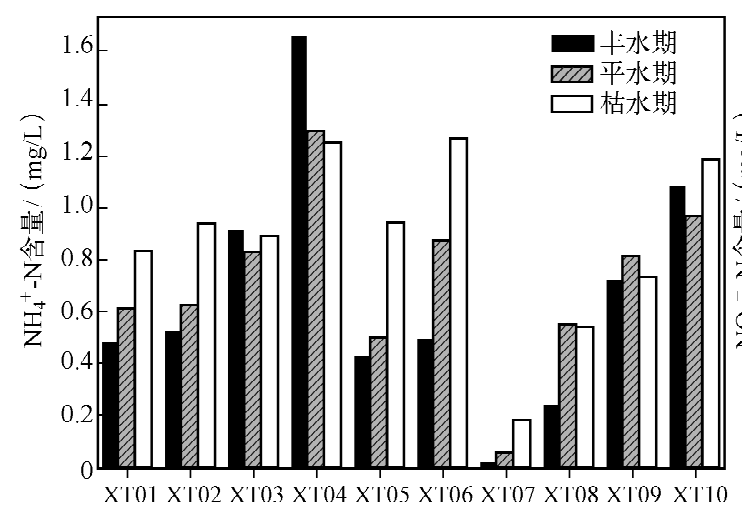

文流编只

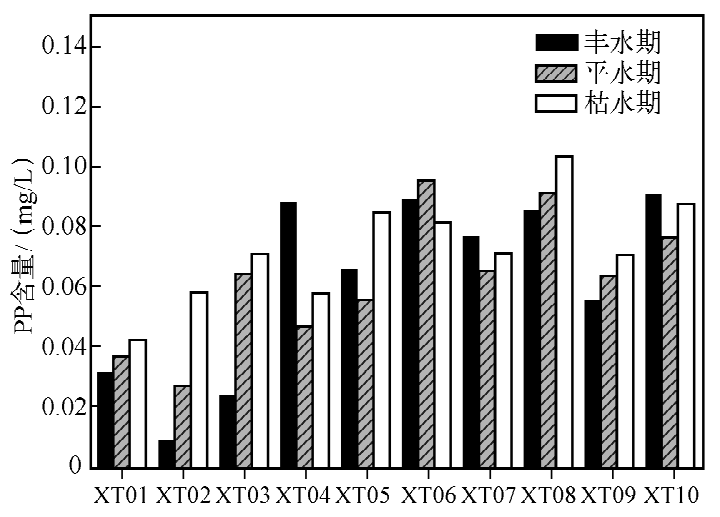

文流编只

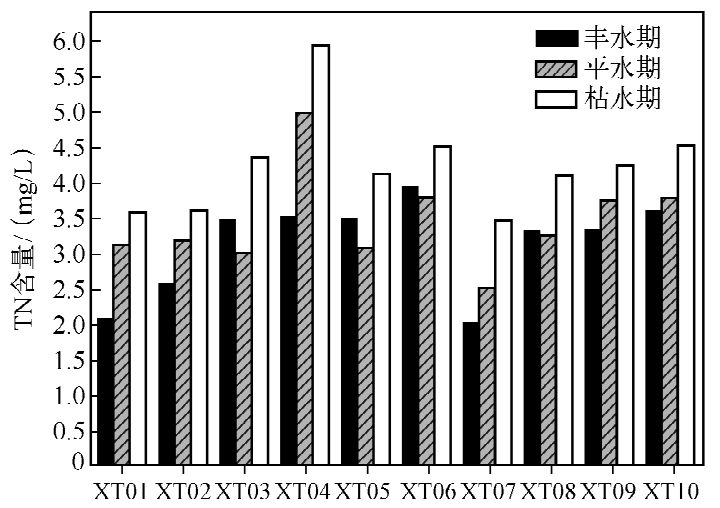

支流编号

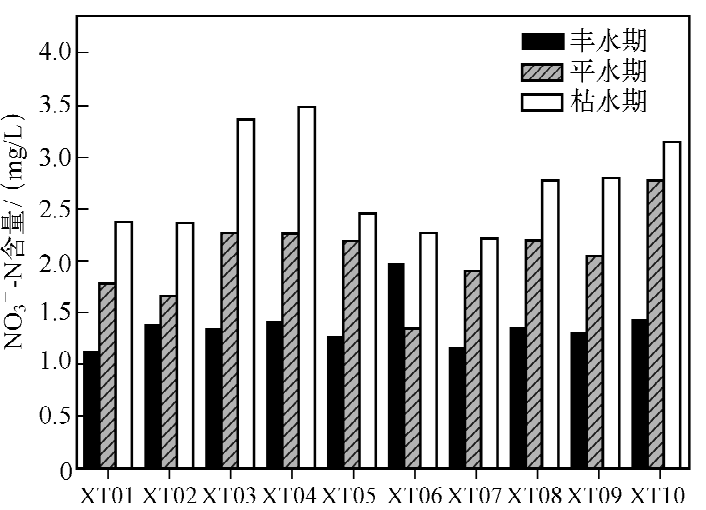

文流编品

图 3 西宕溪支流 $N 、 P$ 含量季节变化

Fig. 3 Distribution of N and P in diverse seasons in tributaries of Xitiaoxi River

标准, 表明西苕溪支流还未受到有机污染的严重影响. 大多数支流枯水期 COD 值高于平水期和丰水期. 与干 流相比 ${ }^{[15]}$,大多数支流的 COD 值低于干流, 对干流而言表现为稀释作用(图 4).

\section{3 西莒溪流域支流的差异性分析}

为了解不同支流营养盐分布特征, 将 10 条支流的 $\mathrm{TP} 、 \mathrm{PP} 、 \mathrm{TN} 、 \mathrm{NH}_{4}^{+}-\mathrm{N} 、 \mathrm{NO}_{3}^{-}-\mathrm{N}$ 和 $\mathrm{COD}$ 含量进行系统聚 类分析. 聚类分析是使用一定的相似距离测度方法不断把性质最接近的 2 类合并成更大的类, 基本原则是 


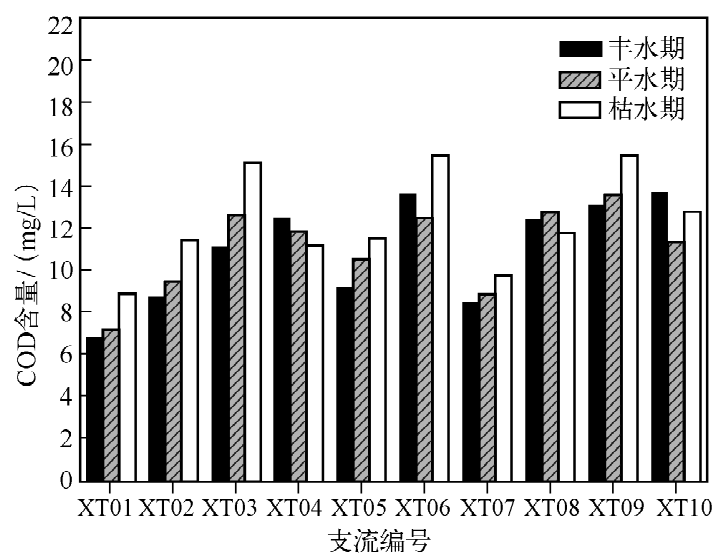

图 4 西苕溪支流 COD 含量季节变化

Fig. 4 Distribution of COD in diverse seasons in tributaries of Xitiaoxi River

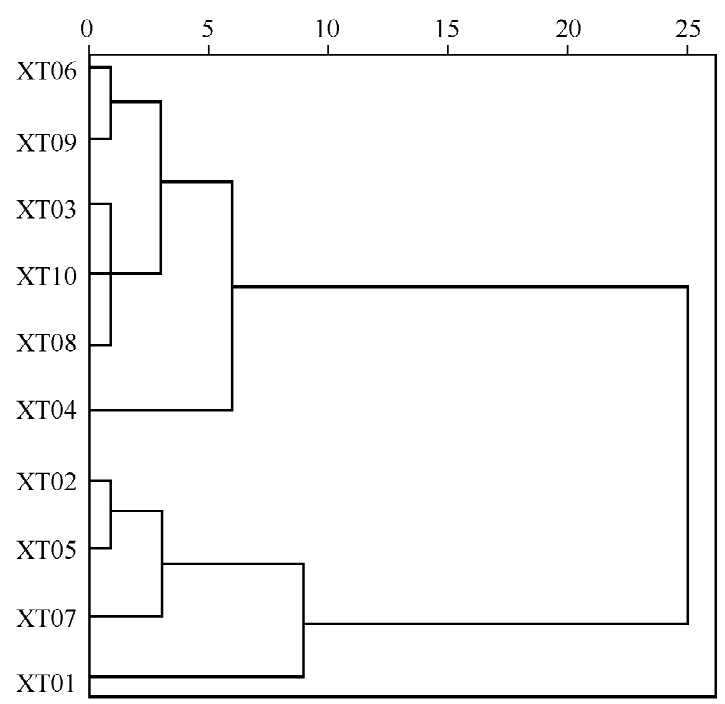

图 5 支流聚类分析结果

Fig. 5 Clustering analysis results for tributaries of Xitiaoxi River
使同一类中个体差异最小, 不同类别之间差异 最大 ${ }^{[17]}$. 聚类分析结果见图 5.

根据污染物含量的不同, 将支流分为 4 类 时结果为: XT03、XT06、XT08、XT09 和 XT10 为一类, 调查发现这几条支流附近林地面积相 对较少, 耕地和居民地所占比例较大, 受耕作 施肥和生活污水的影响, 氮、磷和 COD 含量较 高, 水质较其他支流差; XT02、XT05 和 XT07 为一类, 其氮、磷和 COD 的含量相对较低. 尽 管 XT05 支流附近的居民地比例有所增加, 但 是居民地都在距离支流较远的地方, 故对水质 的影响较弱; XT01、XT04 分别单独为一类, 其 中 XT01 位于西苕溪干流的上游, 林地和草地 比例最大, 附近居民较少, 故水体氮、磷含量都 很低, COD 含量最低. XT04 支流 $\mathrm{NH}_{4}^{+}-\mathrm{N}$ 含量 最高. 调查发现 XT04 附近主要土地利用类型 为林地和耕地, 但是有市政排污口向支流排放 污水, 而且其附近有很多鱼虾养殖塘, $\mathrm{NH}_{4}^{+}-\mathrm{N}$ 含量高与污水排放和鱼虾饵料投加有关.

\section{4 西莟溪流域支流营养盐输出通量分析}

西苕溪支流营养盐、有机物的输人会影响 干流的总体负荷, 进而会影响到太湖水质. 将 支流视作接纳农业污水、生活污水、工业废水 和地表径流等的污染源排口, 计算调查支流营 养盐和有机物的输出负荷. 计算公式为: 营养 盐通量 $(\mathrm{g} / \mathrm{s})=$ 营养盐浓度 $(\mathrm{mg} / \mathrm{L}) \times$ 流量 $\left(\mathrm{m}^{3} / \mathrm{s}\right) \times$ 换算系数.

西苕溪 10 条支流丰水期、平水期和枯水期 的流量如图 6 所示, 计算得到的丰水期、平水期 和枯水期的 TP、TN 和 COD 的输出结果见表 2 . 支流 TP 在 7、10 和 12 月的输出分别为 8.72 、 6.52 和 $3.86 \mathrm{~g} / \mathrm{s}$; TN 输出分别为 $294.44 、 212.90$ 和 $146.35 \mathrm{~g} / \mathrm{s}$; COD 的输出分别为 1015.79 、 668.41 和 $445.49 \mathrm{~g} / \mathrm{s}$. 可见支流输人是干流 氮、磷的重要来源, 支流对西莒溪干流的营养 盐输人应该引起重视. 受流量的影响, 各支流

$\mathrm{TP} 、 \mathrm{TN}$ 和 COD 的输出均为丰水期 $>$ 平水期 $>$ 枯水期. 以流量 $Q$ 为自变量, 分别以 TP、TN 和 COD 为因变量 做一元线性回归分析, 结果表明 TP、TN 和 COD 输出与流量均呈显著正相关, 相关系数均在 0.95 以上. XT10 支流由于流量最大, 其输出也最大, 占 10 条支流总输出的 $25 \%$ 以上; XT08 支流流量最小, 其营养盐输出也 最小, 只占总输出的 $1.0 \% \sim 3.6 \%$.

\section{5 土地利用对支流水质参数的影响}

由于经济的发展和用地结构的调整, 西苕溪流域土地利用类型发生了很大的变化 ${ }^{[18]}$. 土地利用从两方 面作用于河流水环境质量: 一方面通过不同人类活动方式和强度影响营养盐进人水体的输人量, 另一方面 通过用地方式改变地表粗粘度, 从而影响地表径流过程和营养盐进人水体的过程 ${ }^{[19-22]}$. 因此, 西苕溪支流的 
营养状态现状与其土地利用类型有着密不可 分的关系.

将西苕溪 10 条支流的水质指标平均值 与对应流域的土地利用类型面积比例进行 Spearman 相关分析 (表 3) 可以看出, 林地和 草地与 TP、TN 和 COD 都呈负相关关系, 其中 林地与 TP、TN 呈现显著负相关关系, 这是由 于林地和草地一方面可以通过植物根部的截 留作用来减少污染物的地表径流, 另一方面, 林地和草地面积的增加会引起耕地和居民地 的减少, 污染物经过陆域传输衰减之后也相 应减少, 林地、草地对水质指标起汇的作 用 ${ }^{[23-25]}$. 耕地和居民地与 TP、TN 和 COD 呈正 相关,起到了源的作用. 其中, 耕地与 $\mathrm{TP} 、 \mathrm{TN}$ 呈显著正相关, 居民地与 $\mathrm{NH}_{4}^{+}-\mathrm{N}$ 、COD 也呈显 著正相关. 各种农业活动包括农药化肥的施

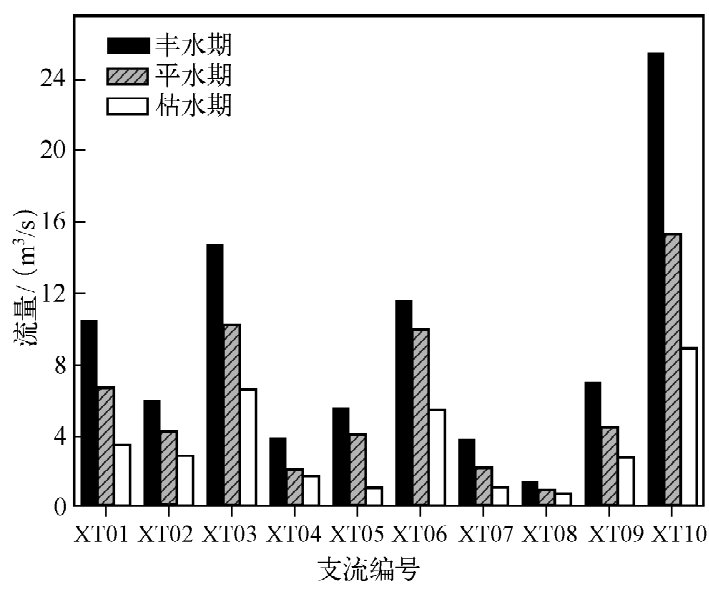

图 6 西苕溪支流流量季节变化

Fig. 6 Flux of Xitiaoxi River tributaries in diverse seasons 用、降雨冲刷、地表径流, 最终通过不同形式进人水体, 造成不同程度的污染 ${ }^{[26-27]}$.

表 2 西宕溪支流营养盐通量 $(\mathrm{g} / \mathrm{s})$

Tab. 2 Fluxes load of TN, TP and COD of tributaries of Xitiaoxi River

\begin{tabular}{|c|c|c|c|c|c|c|c|c|c|}
\hline \multirow{2}{*}{$\begin{array}{l}\text { 支流 } \\
\text { 编号 }\end{array}$} & \multicolumn{3}{|c|}{$\mathrm{TP}$} & \multicolumn{3}{|c|}{$\mathrm{TN}$} & \multicolumn{3}{|c|}{ COD } \\
\hline & 7 月 & 10 月 & 12 月 & 7 月 & 10 月 & 12 月 & 7 月 & 10 月 & 12 月 \\
\hline XT01 & 0.57 & 0.30 & 0.21 & 21.84 & 20.72 & 11.78 & 68.30 & 47.28 & 29.04 \\
\hline ХT02 & 0.19 & 0.21 & 0.21 & 15.03 & 13.01 & 9.66 & 51.64 & 39.23 & 30.85 \\
\hline ХT03 & 0.90 & 0.80 & 0.59 & 51.26 & 36.63 & 28.60 & 163.68 & 127.69 & 98.66 \\
\hline ХT04 & 0.45 & 0.18 & 0.15 & 13.54 & 10.21 & 9.64 & 40.19 & 22.35 & 18.23 \\
\hline XT05 & 0.53 & 0.26 & 0.11 & 19.43 & 12.14 & 4.26 & 50.27 & 41.79 & 11.89 \\
\hline XT06 & 1.49 & 1.46 & 0.74 & 45.43 & 37.23 & 24.22 & 156.07 & 124.11 & 83.37 \\
\hline ХT07 & 0.40 & 0.25 & 0.11 & 7.61 & 5.38 & 3.54 & 32.13 & 19.14 & 9.97 \\
\hline XT08 & 0.16 & 0.11 & 0.14 & 4.49 & 3.31 & 2.76 & 14.62 & 12.63 & 7.93 \\
\hline ХT09 & 0.59 & 0.75 & 0.29 & 23.42 & 17.06 & 11.73 & 87.18 & 61.78 & 42.68 \\
\hline XT10 & 3.45 & 2.21 & 1.30 & 92.40 & 57.22 & 40.17 & 351.71 & 172.42 & 112.85 \\
\hline
\end{tabular}

表 3 土地利用类型与水质指标的 Spearman 相关分析

Tab. 3 Spearman correlation analysis between land use and water quality parameters

\begin{tabular}{crrrrrc}
\hline & $\mathrm{TP}$ & $\mathrm{PP}$ & $\mathrm{TN}$ & $\mathrm{NH}_{4}^{+}-\mathrm{N}$ & $\mathrm{NO}_{3}^{-}-\mathrm{N}$ & $\mathrm{COD}$ \\
\hline 林地 & $-0.681^{*}$ & -0.515 & $-0.794^{* *}$ & -0.612 & -0.527 & -0.430 \\
耕地 & $0.638^{*}$ & 0.600 & $0.879^{* *}$ & 0.394 & 0.394 & $0.745^{*}$ \\
草地 & -0.128 & -0.067 & -0.463 & -0.366 & -0.250 & -0.073 \\
居民地 & 0.506 & 0.164 & 0.596 & $0.632^{*}$ & 0.547 & $0.796^{* *}$ \\
\hline
\end{tabular}

* 表示 $P<0.05$, 显著相关; $* *$ 表示 $P<0.01$, 极显著相关.

为进一步研究土地利用类型对水质的影响,对水质指标与土地利用类型进行逐步多元回归分析. 从表 4 可知,进人多元逐步回归模型的、起显著作用的自变量有林地、耕地和居民地,表明这几种土地利用对营养 盐和 COD 的空间分布影响较大. 空间格局会影响土地利用与水质之间的关系,距离监测点最近的土地利用 情况对于水质的影响要比整个流域的综合土地利用情况对水质的影响更大 ${ }^{[28]}$. 在西苕溪支流流域附近, 主 
表 4 土地利用类型与营养盐输出的 逐步多元回归分析 *

Tab. 4 Regression analysis between land use and water quality index

\begin{tabular}{clc}
\hline 阶段 & 回归分析方程 & $R$ \\
\hline 丰水期 & $\mathrm{TP}=0.297-0.003 \mathrm{FL}$ & 0.755 \\
& $\mathrm{TN}=1.756+0.070 \mathrm{CL}$ & 0.786 \\
& $\mathrm{NO}_{3}^{-}-\mathrm{N}=0.848+0.022 \mathrm{CL}$ & 0.708 \\
& $\mathrm{COD}=29.214-0.247 \mathrm{FL}$ & 0.908 \\
平水期 & $\mathrm{TN}=7.645-0.056 \mathrm{FL}$ & 0.795 \\
& $\mathrm{TP}=0.063+0.008 \mathrm{RL}$ & 0.665 \\
枯水期 & $\mathrm{TN}=2.742+0.075 \mathrm{CL}$ & 0.704 \\
& $\mathrm{COD}=10.301-0.424 \mathrm{FL}$ & 0.674 \\
\hline
\end{tabular}

* FL 代表林地, CL 代表耕地, RL 代表居民地,以百 分比表示.
要土地利用类型为林地,耕地,但是个别支流穿过 城区, 导致尽管居民地的总体比例不高, 但是却出 现在回归模型中.

在丰水期, 建立了 $\mathrm{TP} 、 \mathrm{COD}$ 与林地以及 $\mathrm{TN}$ 、 $\mathrm{NO}_{3}^{-}-\mathrm{N}$ 与耕地的回归方程, 是因为在丰水期水稻种 植带来的农田排水以及较大的雨水冲刷作用, 使得 耕地对氮素的贡献较大,而污染物在径流过程中被 林地截留吸收,使得其对 TP 和 COD 的截留作用较 为明显 ${ }^{[28-29]}$. 在平水期, 建立了 $\mathrm{TN}$ 与林地, $\mathrm{TP}$ 与居 民地的回归方程. 在枯水期, 建立了 $\mathrm{TN}$ 与耕地, COD 与林地的回归方程 (表 4). 耕地对 TN 值的贡 献较大, 是因为枯水期会种植冬小麦油菜等冬季作 物, 化肥农药施肥量会有所增加, 导致含氮化肥 流失.

由上述分析可知，西苕溪支流附近的土地利用 类型是造成不同支流营养元素分布差异的主要成

因. 从空间分布来说, 支流的林地、草地比例升高, 营养元素和 COD 含量降低,耕地、居民地和水体比例增大, 营养元素和 COD 含量升高. 从季节变化来说, 与支流附近的农业耕作方式和地表径流的季节变化有关. 枯水 期降雨量少,通过降雨径流作用从流域输出的非点源污染物含量降低,同时地表径流量降低导致水体的环 境容量减弱,对其中的污染物降解作用降低,因此 12 月份的污染物浓度值较大. 虽然 7 月份频繁的农业活动 中施人的大量氮肥、农药以非点源的形式进人地表水体,导致地表水体中的氮含量增加,但是 7 月份是全年 雨、热量最大的月份之一, 降雨汇流作用导致地表径流量增加, 对其中的污染物有稀释作用, 降低其中的污 染物浓度. 10 月平水期情况,基本上处于丰水期与枯水期之间.

\section{3 结论}

1) 太湖流域上游西苕溪支流水体磷污染和有机污染较轻, 氮污染相对较重. 西苕溪支流流域的营养盐 含量基本上呈现出了枯水期 $>$ 平水期 $>$ 丰水期的特性,营养盐含量空间变化较为显著. 与西苕溪干流相比, 除 TN 含量略高于干流, 其他营养盐含量均低于干流, 对干流表现出稀释作用. 根据营养盐和 COD 含量, 利 用聚类分析可以将支流分为 4 类,每一类的营养特征与周围环境相联系.

2) TP、TN 和 COD 输出均与流量呈显著的正相关关系. 表明流量是营养物输出的关键因素. 西苕溪支流 输人是干流营养盐的重要来源,其营养盐排放应该得到足够的重视.

3 ) 西苕溪支流的土地利用类型与水质的相关性结果表明, 耕地、居民地是营养源的重要贡献者, 林地和 草地起则起到了汇的作用,这给太湖流域的土地管理和水污染控制提供了依据.

4 ) 流域的土地利用结构对水质指标输出浓度影响不同. 在丰水期, 耕地对 $\mathrm{TN} 、 \mathrm{NO}_{3}^{-}-\mathrm{N}$ 影响最大, 林地 对 TP、COD 影响最大; 在平水期, 居民地对 TP 影响最大, 林地对 TN 影响最大; 在枯水期, 对 TN 影响最大的 土地利用类型是耕地,对 COD 影响最大的是林地. 土地利用方式的变化间接影响了干流和太湖的近岸的 水质.

\section{4 参考文献}

［1］吴雅丽,许 海,杨桂军等. 太湖水体氮素污染状况研究进展. 湖泊科学,2014,26(1):19-28.

[ 2 ] Xu H, Paerl HW, Qin B et al. Nitrogen and phosphorus inputs control phytoplankton growth in eutrophic Lake Taihu, China. Limnology and Oceanography, 2010, 55(1):420.

[ 3 ] Lewis JR WM, Wurtsbaugh WA, Paerl HW. Rationale for control of anthropogenic nitrogen and phosphorus to reduce eutrophication of inland waters. Environmental Science and Technology, 2011, 45(24) : 10300-10305.

[4] 胡开明,李 冰,王 水等. 太湖流域 (江苏省) 水质污染空间特征. 湖泊科学, 2014,26(2) :200-206. 
[ 5 ] 何德进,邢友华,姜瑞雪等. 东平湖水体中氮磷的分布特征及其富营养化评价. 环境科学与技术, 2010,33(8): $45-48$.

[ 6 ] 孟 伟,于 涛,郑丙辉等. 黄河流域氮磷营养盐动态特征及主要影响因素. 环境科学学报, 2008, 27 (12): 2046-2051.

[ 7 ] 潘红波. 湖泊富营养化问题及其防治浅议. 环境科技,2011,24(1) :123-126.

[ 8 ] 陈 莹, 尹义星, 陈 爽. 典型流域土地利用/覆被变化预测及景观生态效应分析一以太湖上游西苦溪流域为 例. 长江流域资源与环境,2009,18(8):765-770.

[ 9 ] Wan R, Cai S, Li H et al. Inferring land use and land cover impact on stream water quality using a Bayesian hierarchical modeling approach in the Xitiaoxi River Watershed, China. Journal of Environmental Management, 2014, 133(1):11.

[10］李兆富,杨桂山, 李恒鹏. 基于改进输出系数模型的流域营养盐输出估算. 环境科学,2009,30(3):668-672.

[11］金婧靓,王飞儿,戴露芗等. 苔溪流域非点源污染特征及其影响因子. 应用生态学报,2011,22(8):2119-2125.

[12] 李兆富, 刘红玉, 李恒鹏等. 基于流域单元的营养盐输出与景观异质性影响研究. 环境科学, 2010,31 (9): 2029-2035.

[13］复 盛. 水和废水监测分析方法. 北京:中国环境科学出版社,2002:836.

[14] 张晓晴,陈求稳. 太湖水质时空特性及其与蓝藻水华的关系. 湖泊科学,2011,23(3):339-347.

[15] 李 伟,姚笑颜,梁志伟等. 基于自组织映射与哈斯图方法的地表水水质评价研究. 环境科学学报, 2013,33 (3): 893-903.

[16] Quir SR. The relationship between nitrate and ammonia concentrations in the pelagic zone of lakes. Limnetica, 2003, 22 $(1 / 2): 37-50$.

[17］田盛丰. 聚类分析方法. 计算机研究与发展,1992,29(3):16-20.

[18］陈 莹, 许有鹏, 陈兴伟. 长江三角洲地区中小流域未来城镇化的水文效应. 资源科学, 2011,33(1):64-69

[19］黄金良,李青生,洪华生等. 九龙江流域土地利用/景观格局一一水质的初步关联分析. 环境科学, 2011,32(1)： 64-72.

[20］张殷俊,陈 爽, 相景昌. 河流近域土地利用格局与水质相关性分析一以巢湖流域为例. 长江流域资源与环境, 2011,20 (9): 1054-1061.

[21] 胡 建,刘茂松,周 文等. 太湖流域水质状况与土地利用格局的相关性. 生态学杂志, 2011,30(6):1190-1197.

[22] 于兴修,杨桂山, 欧维新. 非点源污染对太湖上游西芳溪流域水环境的影响. 湖泊科学,2003,15(1):49-55.

[23] Li S, Gu S, Liu W et al. Water quality in relation to land use and land cover in the upper Han River Basin, China. Cate$n a, 2008, \mathbf{7 5}(2): 216-222$.

[24] Li Y, Liu K, Li L et al. Relationship of land use/cover on water quality in the Liao River basin, China. Procedia Environmental Sciences, 2012, 13(14):84-93.

[25] 孙金华,曹晓峰,黄 艺. 滇池水质时空特征及与流域人类活动的关系. 湖泊科学,2012,24(3):347-354.

[26] 聂小飞,李恒鹏, 黄群涁等. 天目湖流域丘陵山区典型土地利用类型氮流失特征. 湖泊科学,2013,25(6):827-835.

[27］荣 洁,曾春芬, 王腊春. 太湖流域 LUCC 对水文过程的影响. 湖泊科学,2014,26(2):305-312.

[28］曹芳芳,李 雪, 王 东. 新安江流域土地利用结构对水质的影响. 环境科学, 2013,34(7):2582-2587.

[29］李恒鹏,杨桂山,黄文䦀. 不同尺度流域地表径流氮, 磷浓度比较. 湖泊科学, 2006,18(4):377-386. 